Yuri Stoyanov (London)

\title{
Medieval Christian Dualist Perceptions and Conceptions of Biblical Paradise
}

Perceptions and conceptions of Biblical paradise in medieval Christian dualism (namely, Paulicianism, Bogomilism and related groups in Eastern Christendom and Catharism in Western Christendom), which led to some major revisionist readings and retellings of the canonical Eden narrative in Genesis 2-3, unlike other dualist doctrinal traditions have not been so far the subject of a systematic analysis. This is certainly to be regretted, since this problem offers the potential to explore an important and promising sphere in the study of medieval Christian dualist heresy, on one hand, and the development and transmutations of medieval notions, imagery and symbolism of paradise. In view of the insufficiently evolved state of research on this subject matter, the present article does not intend to advance a detailed discussion of the all medieval Christian dualist reinterpretations of traditional Paradise themes and narratives against the background of their respective treatment in Gnosticism and Manichaeism as well as early and medieval Christianity. Its main concern is to draw attention to some of the most prominent and symptomatic appropriations of traditional themes of Biblical paradise in medieval Christian dualism and dwell on the important but presently not always explicable problem of their theological and literary provenance. The significance of this specific problem is highlighted by the increasing amount of direct and indirect evidence of the role played by a number of early Jewish and Christian pseudepigraphic works dating from the late Second Temple era and late antiquity (preserved and circulated in various textual and language traditions in medieval Eastern Christendom) in the formation of medieval Christian dualist cosmogonic, cosmological, satanological, Christological and biblical history traditions.

Given the recent and ongoing historiographic controversies regarding the doctrinal nature and history of medieval dissident communities identified as 'Cathar', it will be necessary to briefly discuss the principal forms of medieval Christian dualism and their religio-historical provenance. In the wake of the extensive dissemination (via channels which included textual corpuses like the Nag Hammadi one) of varied Gnostic dualist and related teachings during late antiquity, traces 
and actual individual or community transmitters of such traditions in early medieval Christendom become historically progressively difficult to detect and identify. However, what could be defined as proto-Gnostic, Gnostic-like, Gnosticizing, dualist and semi-dualist notions and elements stemming from such traditions were conserved in a number of pseudepigraphic works of early Jewish and Christian provenance which were circulated among diverse Christian milieux in late antiquity. Amid the theological and Christological controversies in the early medieval East Christian world, despite being censored and ostensibly forbidden by the evolving ecclesiastical elites, such pseudepigraphic texts were preserved and maintained their circulation in a variety of East Christian settings - whether in sectarian, heterodox, monastic or learned circles. In appropriate circumstances such notions and narratives in apocryphal works could trigger revivals of related attitudes through the simple borrowing of their themes or through creative exegeses spreading from these works to the canonical scriptures, with all the potential for the formulation of new heterodoxies and heresies.

The historical evidence of the beginnings and evolution of medieval Christian dualism is admittedly fragmentary and has attracted numerous scholarly controversies but after decades of text critical work on the relevant primary sources it can be concluded that its rise was signalled by the emergence of Paulicianism in the complex and tense religious world of early medieval Armenia. In the course of the centuries following the start of the process of its Christianization in the early fourth century Armenia had become the arena of the political and religious contest of the two great imperial rivals of late antiquity, the Christianized East Roman (Byzantine) and Sasanian Persian empires. There are some indications that with the introduction and progress of increasingly harsh anti-heretical (especially antiManichaean) legislation in the Christian East Roman empire, Christian dissident groups, labelled heterodox and heretical by its institutionalized clerical elite, felt compelled to seek refuge in Armenian lands. In addition the rise and spread of Paulicianism needs to be considered against the background of the characteristic tensions and peculiarities in the early medieval religious climate in Armenianspeaking areas in the Caucasus and eastern Asia Minor. Due to the very fragmentary nature of evidence the early phases and fortunes of the Paulician movement are extremely obscure, making is very difficult to reconstruct their basic outlines.

There is sufficient evidence, however, that Paulicianism began to spread in Byzantine-ruled Anatolian areas early in its history and enjoyed some periods of toleration under the Byzantine iconoclastic emperors. In the following centuries the movement posed some serious problems for the Byzantine secular and ecclesiastical authorities, being predominantly approached and treated by the latter as a revival of Manichaeism - by that time accusations of Manichaeism in Byzantium were used not only against actual or alleged Christian heretics but also to stigmatize religious and political adversaries. Indeed Byzantine descriptions of Paulician 
doctrines as "Manichaean" and dualist have provoked intense and ongoing debates regarding the origins of Paulician teachings and religious observances.

Apart from asserting that the Paulicians adhered to emphatic iconoclasm and rejected the sacraments, prerogatives and hierarchy of the normative church, Byzantine polemical works consistently described the Paulicians as outright Manichaeans and attributed to them the radical dualist doctrine of two gods or principles, the evil creator of the present material world and the good God of the future world. The Paulicians are also described as professing Docetic Christology, according to which Christ's incarnation was proclaimed illusory and the Virgin Mary was praised not as the mother of Christ but as the heavenly Jerusalem ${ }^{1}$.

However, differing readings of references to the Paulicians in Armenian and Byzantine sources have lead to conflicting conclusions as to whether they were originally dualist or embraced dualism later in their history ${ }^{2}$. Assigning priority to the Armenian sources, Nina Garsoïan has strongly challenged the influential view that Paulicianism originated as a dualist heresy, presenting arguments in her wide-ranging reassessment of Paulician history and teachings that both the dualist and Docetic doctrines represent late developments in the Paulician movement, which occurred during its Byzantine period and on Byzantine soil ${ }^{3}$. However, this reappraisal of Paulician religious evolution has not succeeded in explaining convincingly the timing and cause of such posited Paulician doctrinal reorientation in Byzantium; indeed its proposal for a secondary dualist reformation within Paulicianism as well as its bridging of the sources for the heresy has itself met sustained and broad criticism ${ }^{4}$.

1 The principal Byzantine sources on Paulicianism have been edited and collected in: Les Sources grecques pour l'histoire des Pauliciens d'Asie Mineure, ed. C. Astruc, W. Conus-Wolska, J. Gouillard, P. Lemerle, D. Papachryssanthou, J. Paramelle, TM 4, 1970, p. 1-227. A valuable selection of Byzantine sources for Paulician history and teachings have been translated, with commentaries, in: Christian Dualist Heresies in the Byzantine World c. 650 - c. 1450, ed. J. Hamilton, B. Hamilton, ed. coll. Y. Stoyanov, Manchester 1998, p. 57-114, 139-142, 166-175, 259-260. Generally, on the Byzantine sources for Paulicianism, cf. H. GrÉgolre, Les Sources de l'histoire des Pauliciens, BCLSMP 22, 1936, р. 95-114; Р.М. БАРтикян, Источники для изучения истории павликианского движения, Ереван 1961, ch. 2, p. 55-102; N. GarsoÏAn, The Paulician Heresy: A Study of the Origin and Development of Paulicianism in Armenia and the Eastern Provinces of the Byzantine Empire, The Hague-Paris 1967, ch. 1; P. Lemerle, L'Histoire des Pauliciens d'Asie Mineure d'après les sources grecques, TM 5, 1973, p. 1-137.

2 For a discussion of the posited references to and discussions of Paulicianism in the Armenian sources, cf. P.М. Бартикян, op. cit., ch. 1; N. GarsoїAn, op. cit., ch. 2; Christian Dualist Heresies..., Appendix 2, Armenian Sources and the Paulicians, p. 292-293.

3 N. GarsoÏAn, op. cit., with a proposed critical reconstruction of Paulician history, p. 112-151 (ch. 3), and of Paulician doctrine, p. 151-186 (ch. 4); EADEM, Byzantine Heresy. A Reinterpretation, DOP 25, 1971, p. 87-114; EADEM, L'abjuration du moine Nil de Calabre, Bsl 35, 1974, p. 12-27.

4 Cf.: P. Lemerle, op. cit., p. 12sqq. and passim; L. BArnard, The Paulicians and Iconoclasm, [in:] Iconoclasm: Papers Given at the Spring Symposium of Byzantine Studies, March 1975, ed. A. Bryer, J. Herrin, Birmingham 1977, p. 75-83, esp. 81; I.P. Coulianu, The Tree of Gnosis: Gnostic Mythology from Early Christianity to Modern Nihilism, San Francisco 1992, p. 192-194; Christian Dualist Heresies..., Appendix 2, Armenian Sources and the Paulicians, p. 292-293. 
Byzantine reports of Paulician teachings reiterate they professed dualism between the recognized creator-god and ruler of this world and the concealed god of the world to come (who could be seen as lord of heavens). These reports have triggered lengthy and persisting scholarly and theological debates have persisted the veracity of their allegations and whether such dualist teachings could have derived from Manichaean, Marcionite or other dissenting Christian groups' influences ${ }^{5}$. It is also wholly, if not more plausible that the formulation of the Paulician dualist version of Christianity was not the consequence of an actual heretical chain of transmission of ideas but was developed independently through a spiritualist and allegorical reading of the New Testament in sixth-seventh century Armenian sectarian milieus, its dualist element being influenced directly or indirectly by the various dualist survivals still active on the religious scene of late antique and early medieval Armenia, ranging from Zoroastrian to Christian heterodox and possible Gnostic-related residues ${ }^{6}$.

Although it still abounds in major gaps and uncertainties, the history of the rise of the Paulician movement in Armenia, its expansion in Byzantine Anatolia and the re-settlement and migrations of Paulician communities in the Balkans and their later evolution there provides some very valuable evidence of the nature and dynamics of the development, expansion and suppression of religious dualist heterodoxy and heresy along the Caucasus - Anatolia - Balkan axis.

5 For arguments that Manichaeism was in many respects a direct ancestor of Paulicianism which experienced also some Marcionite influences, cf.: D. Oвоцеnsкy, The Bogomils: A Study in Balkan NeoManichaeism, Cambridge 1948, p. 44-47, followed by: Д. АнгЕлов, Богомилството, София 1993, p. 83, 97, an. 57; for arguments that Paulician dualism may have been a development of Marcionite teachings, cf.: A. von Harnack, Marcion: Das Evangelium vom fremden Gott: eine Monographie zur Geschichte der Grundlegung der Katholischen Kirche, ${ }^{2}$ Leipzig 1924, p. 382-383 (with reservations); H.

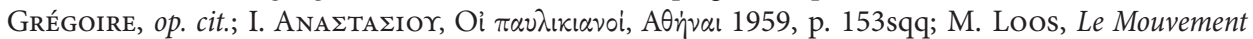
pauliciens à Byzance, Bsl 25, 1964, p. 55-56; M. Loos, Dualist Heresy in the Middle Ages, Prague 1974, p. 34-35; for arguments for Gnostic influences on Paulician dualism, cf.: J.I. von DöLLINGER, Beiträge zur Sektengeschichte des Mittelalters, vol. I, Geschichte der gnostisch-manichäischen Sekten im frühen Mittelater, Munich 1890 [repr. Darmstadt 1968], p. 2-3; H. SöDERBERG, La Religion des Cathares: études sur le gnosticisme de la basse antiquité et du moyen âge, Uppsala 1949, p. 52sqq; cf. the cautious approach to the problem of possible Manichaean and/or Marcionite impact on Paulicianism in: S. Runciman, The Medieval Manichee: A Study of the Christian Dualist Heresy, Cambridge 1947, p. 46-59; cf. the views of I.P. Coulianu, op. cit., p. 190-196, who, while treating Paulicianism as a 'popular Marcionism', argues that the Marcionite influence need not have been a direct historical one. Cf. also: P. LEMERLE, op. cit., p. 132-135, for a discussion of the parallels and the important differences between Marcionism and Paulicianism, and an emphasis on Paulician reinstatement of evangelical Christianity and the Pauline tradition.

6 Cf. B. Hamilton, Historical Introduction, [in:] Christian Dualist Heresies..., p. 7-8; Y. Stoyanov, The Other God. Dualist Religions from Antiquity to the Cathar Heresy, London-New Haven 2000, p. 125-129; on fifth-century reports of trends and movements in Armenian Christianity perceived as Gnostic-related, cf. V.N. Nersessian, The Tondrakian Movement: Religious Movements in the Armenian Church from the Fourth to the Tenth Centuries, London 1987, p. 79sqq. 
The evolution of medieval Christian dualism entered a new, crucial stage with the rise of the Bogomil heresy in the first half of the tenth century in the newly and to some extent re-Christianized central and eastern Balkans. Medieval Orthodox polemicists tended to apply to Bogomilism the heresiological cliché of "Manichaean heresy" or to define it as a combination of earlier heresies - such perceived combinations could involve admixtures of Manichaeism and Paulicianism, Paulicianism and Massalianism or else Manichaeism and Massalian$\operatorname{ism}^{7}$ (condemned as heretical, Massalianism, with its characteristic anthropological dualism had followed a similar trajectory of diffusion from north-east Mesopotamia to Syria, Armenia and Asia Minor). Such clear-cut heresiological definitions of Bogomilism can be extremely misleading but sometimes have been adopted in earlier scholarship in which the direct influences of earlier Manichaean, Marcionite or separate Gnostic traditions were also variously assumed to have their impact on the formation of Bogomil dualist teachings ${ }^{8}$. The most recent and evolving trends of research into the accelerated process of the formation of Slavo-Byzantine Orthodox theology, culture and learning in the late ninth and tenth centuries, as developed by the Ohrid and Preslav literary schools of the newly Christianized Bulgarian kingdom, however, have made available more material, and presented strong arguments suggesting that the conceptualization and elaboration of Bogomil theological dualism owes much to this diverse process. Significantly, not only were the scriptures translated in a language sufficiently close to the vernacular, but the wide-ranging translation and diffusion of ostensibly censored pseudepigraphic texts also took place during its initial phases 9 .

By the early eleventh century Bogomilism had penetrated Byzantine territories in Anatolia and was to spread further into peninsular Greece, the west-

7 Cf. for example: Theophylact Lecapenus, Epistula, [in:] I. Duichev, L'epistola sui Bogomili del patriarca constantinopolitano Teofilatto, [in:] Mélanges Eugène Tisserant, Città del Vaticano 1964, p. 89-91; Anna Comnena, Alexiad, XV, 10, 3-4, ed. B. Leib, Paris, 1945, III, p. 227sqq.; Pseudo-Psellus, De daemonibus, [in:] Le 'De Daemonibus'du Pseudo-Psellus, ed. P. GAUtier, REB 38, 1980, p. 105-194.

8 See the summary of earlier and more recent approaches to the provenance of Bogomili dualism in: Y. Stoyanov, op. cit., p. 161-166.

9 For earlier views about this process, cf., for example, Й. Иванов, Богомилски книги и легенди, София 1925; E. TuRdeAnu, Apocryphes bogomiles et apocryphes pseudo-bogomiles, RHR 138.1, 1950, p. 22-52; 138.2, p. 176-218; N. MINISsi, La tradizione apocrifa e la origini del bogomilismo, RS 3, 1954, p. 97-113; see the critical survey of more recent explorations of this phenomenon in: Y. STOYANov, op. cit., p. 260-287 passim; Y. Stoyanov, Apocryphal Themes and Apocalyptic Traditions in Bogomil Dualist Theology and their Implications for the Study of Catharism, PhD Diss., University of London 2000, p. 67-73, 213-236; see also the bibliography on the subject of the interrelations between Bogomilism and apocryphal literature in: A. OrLov, Selected Bibliography on the Transmission of the Jewish Pseudepigrapha in the Slavic Milieux, [in:] IDEM, Selected Studies in the Slavonic Pseudepigrapha, Leiden 2009, p. 203-435 (418-423). 
ern Balkans (particularly in Dalmatia and Bosnia). In the period of the crusades when the contacts and interchange between Eastern and Western Christendom greatly intensified, Bogomilism reportedly made missionary advances further to the west. While it is still impossible to establish a detailed picture of the interrelations between Bogomilism and the early Cathar communities in western Europe, a number of Western sources refer to a formative missionary and theological impact Eastern Christian dualists on early Catharism. The nature and extent of this impact (or even it existed at all) has remained the subject of vigorous and ongoing scholarly debate, which has acquired further topicality following some very recent studies, questioning the existence of a coherent dualist doctrinal system and organizational structures and hierarchy among groups labelled as 'Cathar' in Catholic polemical and historical sources ${ }^{10}$.

Original Bogomil dualism had a monarchian or moderate character which clearly contrasted with the mature Paulician radical dualist dogma of the two principles, the evil creator of this world and the good Lord of the world to come. The cumulative evidence of a number of primary sources indicates that by the last three decades of the twelfth century both Bogomil and the related Cathar dualism divided into two strands, a monarchian and a radical trend, which advanced different versions and narratives of Christian dualism (while the existence of intermediary forms of dualism or more monistically-inclined Bogomil groups and theologians should not be dismissed).

All versions of Bogomil and Cathar dualism had a strongly anti-cosmic, anti-somatic character. Significantly, in the accounts of both versions of Bogomil and Cathar dualism one may detect notions and narratives, variously related, for example, to apocryphal embellishments of the Genesis creation and flood stories, apocryphal and heretical satanologies and Christologies, etc., that cannot be discovered in the teachings of anti-ecclesiastical and heretical movements preceding the emergence of Bogomilism and Catharism but can be found in the various pseudepigraphic works that came to be translated and circulated in various Slavo-Byzantine contexts and milieus before and during the formation and evolution of Bogomil dualist theology ${ }^{11}$. It was from such pseudepigraphic works like The Book of the Secrets of Enoch (2 Enoch) ${ }^{12}$, The Apocalypse

\footnotetext{
${ }^{10}$ In particular: M.G. PEgG, The Corruption of Angels: the Great Inquisition of 1245-1246, Princeton 2001; IDEM, A Most Holy War: the Albigensian Crusade and the Battle for Christendom, New York-Oxford 2008; R.I. Moore, The War on Heresy: Faith and Power in Medieval Europe, London 2012.

${ }^{11}$ See the analysis of the evidence of primary sources, including critical surveys of existing studies touching on this problematic, in: Y. STоуаNov, Apocryphal Themes and Apocalyptic Traditions..., chs. 2, 3 and 4.

12 The first edition of the apocalypse as a whole was prepared by A. I. Popov in 1880 (based on a late seventeenth-century Russian manuscript of the long recension), А.И. Попов, Библиографические материалы собранные А.Н. Поповым, ЧИОИДР 3.9, 1880, p. 66-139, while in 1884 S. Novaković published for the first time a manuscript of the short recension: S. Novaković, Apokrif o Enohu, Star 16,
} 
of Abraham ${ }^{13}$ and The Greek Apocalypse of Baruch (3 Baruch) ${ }^{14}$ that Bogomilism appropriated and developed some of its most important notions which later became influential in western Catharism such as its multi-heaven cosmology, crucial features of its diabology, elements of its cosmogony and a number of eschatological traditions.

This brief introductory survey on the state of research on the types and provenance of pseudepigrahic works and the patterns of their impact on medieval Christian dualism were essential for providing the necessary religio-historical context for the discussion of the roots of its notions and narratives of biblical Paradise. Accounts of and polemics against moderate Christian dualism in medieval Eastern and Western Christendom generally focus on its tenet of the Devil (otherwise a secondary and inferior agency to God the Father) as a maker or architect

1884, p. 67-81. The subsequent discoveries of more manuscripts belonging to both recensions led to a continuous textual debate focused on the problem which one of two is closest to the original Slavonic translation of the apocalypse and occasionally, whether there exists a third intermediate version. For a bibliography of the editions, translations and studies of 2 Enoch, see A. OrLOv, op. cit., p. 222-243.

${ }_{13}$ Like 2 Enoch and The Ladder of Jacob The Apocalypse of Abraham is extant only in Slavonic manuscripts. The Slavonic version of The Apocalypse of Abraham has been preserved in a more or less full form in nine Russian manuscripts, the earliest of which date from the fourteenth century and was published in 1863 separately by: Н.С. Тихонравов, Памятники отреченной русской литературы, vol. I, Москва 1863, p. 32-53, and И.И. СРезневский, Древние памятники русского письма и языка: общее повременное обозрение, Санкт-Петербург 1861-1863, col. 648-665. Recent critical editions of the apocalypse were published separately by B. Philonenko-Sayar, M. Philonenko, L'Apocalypse d'Abraham. Introduction, text slave, traduction et notes, Paris 1981, and R. RuBINKIEwICZ, L'Apocalypse d'Abraham en vieux slave: Introduction, text critique, traduction et commentaire, Lublin 1987. The recent important textual critical study of the apocalypse by A. Kulik includes an English translation of the text: A. Kulıк, Retroverting Slavonic pseudepigrapha: toward the original of the Apocalypse of Abraham, Atlanta 2004, p. 9-37. For a bibliography of the editions, translations and studies of The Apocalypse of Abraham, cf. A. OrLov, op. cit., p. 246-256.

14 The Greek Apocalypse of Baruch (3 Baruch) has been a subject of academic study for more than a century. In $1886 \mathrm{~S}$. Novaković published the text of a Slavonic version of the apocalypse for the first time (from a fifteenth-century Serbian manuscript): S. Novaković, Otkrovenjie Varuhovo, Star 18, 1886, p. 203-209, and in 1897 M.R. James presented an edition of the Greek text: M.R. James, The Apocalypse of Baruch, [in:] Apocrypha Anecdota II (TS 5.1), ed. J. RoBInson, Cambridge 1897, p. lilxxi, 83-94. The subsequent discoveries and publications of more manuscripts of 3 Baruch led to a continuous textual debate focused on the problem of the relationship between the Greek and Slavonic versions and the Slavonic textual tradition. The study of 3 Baruch was greatly enhanced by the critical editions of the Greek version of the apocalypse by J.-C. PICARD, Apocalypsis Baruchi Graece, Leiden 1967, and its Slavonic version by: H. GAYLORD, The Slavonic Version of 3 Baruch, PhD Diss., Hebrew University of Jerusalem 1983, which were followed by the major studies the apocalypse by D.C. Harlow, The Greek Apocalypse of Baruch (3 Baruch) in Hellenistic Judaism and Early Christianity, Leiden 1996, and most recently: A. KulIK, 3 Baruch: Greek-Slavonic Apocalypse of Baruch, Berlin and New York 2010, which includes a very valuable new English translation of and commentary on the apocalypse, p. 89-386. For a bibliography of the editions, translations and studies of The Apocalypse of Abraham, cf. A. OrLov, op. cit., p. 278-284. 
of the visible world and terrestrial creation ${ }^{15}$. Accordingly such accounts can emphasize the role of the Devil as a creator of paradise as in the case of the important source on eleventh-century Anatolian Bogomilism (and related groups), Euthymius of Peribleptos' Epistola ${ }^{16}$. The creation of Paradise and its position in the structure of the visible cosmos in such reported moderate dualist teachings is brought thus into the framework of a tradition of biblical exegesis in which, as in earlier Gnostic traditions, the Creator, the God of the Old Testament is identified as an inferior demiurge and reveals that above him there exists an invisible Father, against whom he raises a revolt in heaven.

The attribution of the creation of Paradise to this inferior biblical demiurge, represented as a secondary "satanic" power, is highlighted in the Bogomil apocryphon, Interrogatio Iohannis (the most detailed and significant internal source of medieval moderate Christian dualism ${ }^{17}$ where it is generally synchronized with the other Creator's feats in Genesis 1-2. As with the other biblical acts of creation ascribed to the secondary "satanic" power in the Bogomil apocryphon, the fashioning of Paradise occurs in the wake of Satan's fall from heaven to the firmament following his rebellion against the Father. As in earlier Gnostic systems, Interrogatio Iohannis lays a special emphasis on its rendition of the Genesis Garden of Eden narrative and its theodicy, the Edenic fortunes of the first human couple, the identity of the Edenic serpent who tempted Eve to eat the forbidden fruit of the Tree of Knowledge of Good and Evil and the nature of the Tree itself ${ }^{18}$. In its

${ }_{15}$ See, for example, Presbyter Cosmas' tenth-century Sermon Against the Heretics, newly edited in: Ю. Бегунов, Козма презвитер в славянских литературах, София 1973, p. 305, 327, 331; МоNетА оғ Cremona, Adversus Catharos et Waldenses libri quinque, ed. T.A. Ricchini, Rome 1743, Book 1, Preface, p. 2sqq.

16 The text of Euthymius' Epistola is preserved in five manuscripts but only two contain the whole text. The letter is contained in $P G$, vol. CXXXI, col. $47-58$, but is erroneously attributed to a later theologian, Euthymius Zigabenus (see an. 22 below). Another edition is to be found in: G. Ficker, Die Phundagiagiten: Ein Beitrag zur Ketzergeschichte des byzantinischen Mittelalters, Leipzig 1908, p. 3-86 (the reference to the belief he attributes to the Bogomils/Phundagiagites that the Devil is maker on paradise is on p. 33).

17 The apocryphon is extant only in Latin and divides into two main versions; the first version derives from a manuscript once in the archives of the Inquisition at Carcassonne but subsequently destroyed: it survives in two late manuscripts and one printed text which was published in: J. BENOIST, Histoire des Albigeois et des Vaudois ou Barbets, Paris 1691, vol. I, p. 283-296. Subsequent reprints included that of J.C. Thilo, Codex apocryphus Novi Testamenti, Leipzig 1832, vol. I, p. 884-896. The second version is represented solely by a manuscript preserved in the National Library of Vienna, apparently dating from the twelfth-thirteenth centuries. The Carcassonne version was reproduced alongside the Vienna version by: М. Соколов, Славянская книга Еноха праведнаго, Москва 1910, p. 165-175; also by: Й. Иванов, ор. cit., p. 73-87, R. ReItzenstein, Die Vorgeschichte der christlichen Taufe, Leipzig-Berlin 1929, p. 297-311, and in the most recent critical edition of text, E. Bоzóкy, Le Livre secret des cathares, Paris 1980, p. 41-94.

18 On Gnostic approaches and reworkings of the Genesis Paradise narrative and related conceptualizations of the theme of Paradise, see, for example, R. vAN DEN BRoEK, The Shape of Edem According to 
reworking of the Genesis Paradise story and the fall of Adam and Eve Interrogatio Iohannis develops a variant of the tradition attested in earlier Gnostic systems regarding the Gnostic demiurge's (or his demonic archons') sexual encounter with or assault on Eve (or her "likeness"), which find parallels in Jewish rabbinic traditions concerning Eve's seduction by Samael/Satan (who could be identified or associated with the Edenic snake) and their progeny (Pirke de-Rabbi Eliezer 22; Targum-Pseudo-Jonathan 5, 1-3) ${ }^{19}$. According to Interrogatio Iohannis Satan created paradise with the explicit purpose to seduce the first human couple to commit $\sin ^{20}$; he planted in the middle of it a bed of reeds and made the serpent ${ }^{21}$; he forbade Adam and Eve to eat the fruit of good and evil but having entered the serpent, allured Eve into $\sin ^{22}$ (according to one of the glosses to the Vienna version, posing as a beautiful youth ${ }^{23}$ ). Adam was also affected by Satan with a lust

Justin the Gnostic, VC 27, 1973, p. 35-45; M. TARDIEU, Trois mythes gnostiques: Adam, Éros et les animaux d'Égypte dans un écrit de Nag Hammadi (II, 5), Paris 1974; P.S. Alexander, The Fall into Knowledge: The Garden of Eden/paradise in Gnostic Literature, [in:] A Walk in the Garden, ed. P. Morris, D. SAWYer, Sheffield 1992, p. 91-104; J. MaGne, From Christianity to Gnosis and From Gnosis to Christianity: An Itinerary through the Texts to and from the Tree of Paradise, Atlanta 1993 (Magne's thesis considers the reciprocal interpretation of the Emmaus and Paradise narrative as the key to the origins of Gnosticism and Christianity, offering a new chronology of these interpretations in the framework of JewishGnostic-Christian interrelations; Magne argues that the paradise narrative in the Gnostic writings is the fundamental, central core around which and for which everything is organized, p. 73, and the Gnostic movement would have sprang directly... from the exegesis of the Paradise narrative revealed by the Emmaus narrative..., p. 59); T. RAsimus, Paradise Reconsidered in Gnostic Mythmaking: Rethinking Sethianism in Light of the Ophite Evidence, Leiden 2009.

19 For Gnostic elaborations of the theme of Eve's seduction or attempted seduction by the demiurge, his oppressive archons or the chief archon in the Nag Hammadi tracts, see The Apocryphon of John, 24, 8-28; The Apocalypse of Adam, 66, 25 - 66, 10; The Hypostasis of the Archons, 89, 17-28; On the Origin of the World, 116, 5 - 117, 20; For a comparative survey of the theme of Eve's seduction in Gnostic (original and reported) and Jewish traditions, see G.A.G. STroumsa, Another Seed: Studies in Gnostic Mythology, Leiden 1984, p. 35-53. For further evidence concerning Gnostic and Gnostic-related teachings about Eve's seduction by the demiurge or his archons (or authorities), which maintained their currency among the schismatic Audians in the Holy Land, see H.-C. Puech, Fragments retrouvés de l'Apocalypse d'Allogéne, [in:] IDEM, En quête de la Gnose, vol. I, La Gnose et le temps et autres essays, Paris 1978, p. 271-300.

20 Initiator autem peccati cum sua seductione ita fecit: plantavit paradisum et misit hominess intus et precepit eis ne comederent ex eo - Interrogatio Iohannis (Vienna version, 94-95), [in:] E. BоzóкY, op. cit., p. 58.

${ }^{21}$ Diabolus intravit in paradisum et plantavit arundem in medio paradisi et de sputo suo fecit serpentem et precepit ei in arundine manere et sic diabolus ascondebat sapientiam sue fraudis ut non viderent deceptionem suam - Interrogatio Iohannis (Vienna version, 96-99), [in:] E. Bоzóкy, op. cit., p. 60.

${ }^{22}$ Et intrabat et loquebatur ad eos dicens: De omni fructu qui est in paradise, comedite, de fructu vero scientie boni et mali nolite comedere. Et iterum intravit dyabolus in serpentem nequam et seduxit angelum qui erat in forma mulieris et effidit super ea concupiscentiam peccatorum et fecit concupiscentiam suam cum Aeva in cauda Serpentis - Interrogatio Iohannis (Carcassonne version, 93-99), [in:]. E. BozóKY, op. cit., p. 60. ${ }^{23}$ Serpens non fuit ut serpens sed sicut homo. Fecit enim se sicut pulchrum adolescentem et preceptum diaboli introivit in paradisum per canam et decepit mulierem et fornicatus est cum ea cum cauda - Interrogatio Iohannis (Vienna version, Gloss 7, 31-33), [in:] E. BozóKy, op. cit., p. 90. 
for intercourse with Eve and they begot together the 'children of the devil and of the serpent' and Satan's reign, itself dependent on procreation, would last until the consummation of this age ${ }^{24}$.

The Devil's creation of Paradise, his seduction of Eve and infecting Adam with a lust for debauchery (leading to procreation) represents a crucial stage of his designs to imprison the divine substance in humanity in matter (at an earlier stage of the anthropogonic process he condemned the angels of the first and second heaven to suffer bodily imprisonment in mortal, respectively male and female, forms $\mathrm{s}^{25}$. By introducing (and enacting with Eve) longing for sin and lust for debauchery into Paradise, Satan fortifies humanity's exile in matter. The relation of this "satanic" Eden's relation to the creation and structure of the physical world is defined by its central role in this process of imprisoning the protoplasts in the flesh and magnifying humanity's plight by subjecting it to the catastrophic (for its spiritual substance) chain of procreation.

The Paradise episode of Eve's seduction by Satan is also briefly recounted in the very important twelfth-century polemical source on contemporaneous moderate dualist Bogomilism, Euthymius Zigabenus' Panoplia Dogmatica ${ }^{26}$. In Zigabenus' account Adam and Eve were envisaged as being created in a kind of cooperation between Samael/Satanael and God (their bodies were moulded by the former but received God's breath of life). Satanael (Samael) became jealous of them and started to plot against their descendants, thus making his first breach in his contract with God concerning the creation of man and the fortunes of his generations. Again through the medium of the serpent (into which he slipped) he deceived and seduced Eve and she begot from him twins, Cain and his sister Calomena, while Abel is born after her later human union with $\mathrm{Adam}^{27}$. Elements of this Paradise narrative of Eve's seduction by Satan and (on occasions) the ensuing Cainite line are recounted or alluded to in some of the standard Catholic polemical accounts of moderate Cathar dualism ${ }^{28}$.

\footnotetext{
${ }^{24}$ Et iterum effudit dyabolus in angelo qui erat in Adam, venenum suum et concupiscentiam que generat filios serpentis et filios dyaboli usque ad consummationem hujus seculi - Interrogatio Iohannis (Carcassonne version, 101-104), [in:] Е. Воzóкү, op. cit., p. 62.

${ }^{25}$ Et precepit angelo secundi celi introire in corpus luti et tulit de eo et fecit alium corpus in forma mulieris precepitque angelo primi celi introire in illum. Angeli ploraverunt multum videntes super se formam mortalem esse in divisis formis - Interrogatio Iohannis (Vienna version, 87-90), [in:] E. Bozóky, op. cit., p. 58.

26 Euthymius Zigabenus, Panoplia Dogmatica, $P G$, vol. CXXX (cetera: Euthymius Zigabenus); the Bogomil section comprises col. 1289-1331; another version of the Bogomil section is also edited by G. Ficker in: G. FICKer, op. cit., p. 89-111.

27 Euthymius Zigabenus, col. 1297.

${ }_{28}$ Bonacursus, Manifestatio haeresis catharorom quam fesit Bonacursus, PL, vol. CCIV, col. 775792(776); Moneta of Cremona, op. cit., p. 145; Georgius, Disputatio inter Catholicum et Paterinum hereticum, [in:] Thesaurus novus anecdotorum, ed. E. Martène, U. DuRAnd, vol. V, Paris 1717, col. 1705-1753 (1710-1711); Salvo Burci, Liber supra Stella, ed. I. Da Milano, Il 'Liber supra Stella' del
} 
Apart from the earlier and already discussed Jewish and Gnostic traditions, the theme of Eve's seduction by an inferior demiurge, Satan (or Samael) in paradise is also present in 2 Enoch 31, 6 in which Satanael (to be transformed in Sa$\tan )$ begins to plot against Adam, enters paradise and seduces Eve ${ }^{29}$. Unless this narrative represents itself a Bogomil interpolation, given the fact that 2 Enoch served as an important source for Bogomil teachings, this diabological section in 2 Enoch certainly would have influenced or reinforced the Bogomil preoccupation with and elaboration of this Paradise theme. Furthermore, the association between the Devil, a tree in paradise (whether the tree of the knowledge of good and evil or some other tree) and the sin of Adam and Eve seen as related to lust or sexual union is present in the Slavonic version of 3 Baruch 4, 8 where Satanael plants in paradise the vine which is defined as the tree through which the serpent seduced Adam and Eve and was also the sinful desire that Satanael spread over them $^{30}$ (the Greek texts of 3 Baruch also identify the tree that deceived Adam with the vine but lack the theme of tree as a sinful desire).

A similar association occurs in The Apocalypse of Abraham 23, 5-12 where Abraham, after asking who was the one who seduced Eve and what was the fruit of the tree, is granted a vision of paradise in which he sees Adam entwined with Eve under a tree whose fruit has the appearance of a bunch of grapes, held and fed to the couple by a dragon with human hands and feet, identified with Azazel. Again, the tree that caused the Fall, the sexual union of Adam and Eve and the figure of God's adversary (in the case of this apocalypse, Azazel) are interrelated in Abraham's synthetic vision of the Garden of Eden ${ }^{31}$.

The association between paradise and its primordial tree(s) with the bodily/ sexual human passions made explicit in Interrogatio Iohannis (and the moderate Christian dualism it represents ${ }^{32}$ is thus largely shared in the Slavonic version of 3 Baruch and The Apocalypse of Abraham and was most likely formed under the impact of these pseudepigrapha. This association finds also parallels in earlier Gnostic traditions manifested, for example, in the Nag Hammadi tract, Apocryphon of

\footnotetext{
piacentino Salvo Burci contro i catari e altri correnti ereticali, Ae 19, 1945, p. 314. The interrelations between the representation of the association between the sexual union of Eve with Satan and Adam with the forbidden fruit of the Tree of Knowledge of Good and Evil is observed by: E. Bozóky, op. cit., p. 136.

292 Enoch 31, 6 (Long version), MS Belgrade, National Library No 321, reproduced in: М. Соколов, op. cit., p. 31; Й. ИвАНОВ, ор. cit., p. 178.

303 Baruch 4, 8 (Slavonic version), MS Belgrade, National Library No 651, published in: Й. ИвАнов, op. cit., p. 196. For the variant readings of the passage in other Slavonic manuscripts of 3 Baruch, cf. H. GAYLORD, op. cit., p. 46-47.

31 The Apocalypse of Abraham, 23, 5-12; text in: B. Philonenko-Sayar, M. Philonenko, op. cit., p. 88.

32 See, for example, the association between the forbidden tree and fornication in the moderate Cathar dualist teachings recounted in: De heresy catharorum, [in:] La Hiérarchie cathare en Italie, II, De heresy catharorum in Lombardia, ed. A. DondaIne, AFP 19, 1949, p. 306-312 (310): Et dicunt quod comestio ligni prohibiti fuit fornicatio...
} 
John and Justin the Gnostic's Book of Baruch ${ }^{33}$. Another earlier Gnostic tradition which links Eve with the Tree of Knowledge (in the Nag Hammadi tract The Origin of the World while being sexually pursued by archons Eve hid herself into the Tree of Knowledge, leaving behind for them only an earthly resemblance of herself) finds a noteworthy resonance in one of the fifty articles of Patarene/"Manichaean" beliefs reportedly renounced by three "heretical" Bosnian noblemen before Cardinal Torquemada in $1461^{34}$. According to article 12 of the list, the Tree of Knowledge of Good and Evil was envisaged as a woman and after Adam sinned with her, was expelled from Paradise - this belief could have been indeed ascribed to the Bosnian noblemen on the basis of inquisitorial records of earlier medieval dualist teachings ${ }^{35}$ but do suggest that these teachings comprised a more detailed and Gnostic-like rewriting of the Genesis Paradise story than the extant evidence allows one to reconstruct. This is also confirmed by the reported Cathar teaching allegorizing the Tree of Knowledge of Good and Evil as a woman's womb in Georgius, Disputatio inter Catholicum et Paterinum hereticum ${ }^{36}$ which becomes the target of a bitter polemical attack in this text, arguing that woman cannot be associated with Paradise, nor the tree in its midst with her womb.

This is also demonstrated by a gloss to the Interrogatio Iohannis' Paradise episode in the Vienna version which recounts in a slightly more elaborate detail the planting of Paradise, the type of trees planted, including the characteristic cosmographic detail that Satan surrounded it by a ring of fire and dwelling on its essentially evil nature ${ }^{37}$. Some of the motifs of Interrogatio Iohannis' episode of Satan's planting of Paradise appear interrelated with similar themes which emerge in medieval Slavonic apocryphal texts of compilatory nature such as the cycle of The Legend of the Wood of the Cross, attributed to Gregory of Nazianzus ${ }^{38}$, the erotapocritic work, Razumnik $k^{39}$ and in the sixteenth-century South Slavonic cosmogonic text On the Beginning of the World ${ }^{40}$. In the first two works Satanael/Samael is charged with

\footnotetext{
${ }^{33}$ Justin the Gnostic's Book of Baruch is reproduced in: Hippolytus, Refutatio Omnium Haeresium, V, 26-27 (it is not certain whether the text he reproduces, presents the text fully or partially).

${ }_{34}$ These Patarene articles are refuted in: JuAN Torquemada, Symbolum pro informatione manichaeorum, ed. N.L. Martinez, V. Proano, Burgos 1958. English translation and a useful commentary in J.V.A. Fine, The Bosnian Church: A New Interpretation, New York and London, 1975, p. 355-357 [repr. London 2007], p. 280-286. Attention to this article in the context of earlier and similar Gnostic beliefs was drawn by S. Gero, The Seduction of Eve and the Trees of Paradise: A Note on a Gnostic Myth, HTR 71, 1978, p. 299-301.

35 As argued by J.V.A. Fine, op. cit., p. 282.

36 Georgius, op. cit.

37 Interrogatio Iohannis (Vienna version, Gloss 6, 23-30), ed. E. Bozóкy, op. cit., p. 90.

38 Recent edition in А. Милтенова, Текстологически наблюдения върху два апокрифа (Апокрифен иикъл за крбстното дврво приписван на Григорий Богослов и апокрифа за Адам и Ева), СЛ 11, 1982, p. 44-55.

39 Editions of the text include Й. Иванов, op. cit., p. 264-273.

40 Published in: Й. Иванов, op. cit., p. 322-323.
} 
stealing seeds from Paradise and planting them on his own, was exposed and challenged by God to confront the tree he has stolen and planted and as a consequence he was blackened and expelled by the tree itself from Eden ${ }^{41}$. Apart from the theme of Satan planting a vine and introducing sinful passion in Paradise to lead Adam astray, the third apocryphal legend, On the Beginning of the World, offers further parallels to Interrogatio Iohannis in its account of Satanael's entry into paradise to deceive Adam and Eve and assuming the shape of a serpent with the head of a mai$\mathrm{den}^{42}$. The evolving study of the intertextual links between pseudepigrapha-based notions and narratives in Bogomilism and these particular cycles of apocryphal works, focused on cosmogony, cosmology and biblical history will certainly shed new light on the provenance and main features of the Paradise material shared and re-interpreted by these two streams of medieval appropriation and revisions of earlier pseudepigraphic works.

Descriptions of the creation of Paradise and rewriting of the Genesis story also occur in other pseudepigraphic texts circulated in the medieval Slavonic Orthodox world such as the Slavonic version of the Life of Adam and Eve, The Sea of Tiberias and the Battle between Archangel Michael and Satanael about which it has been continuously argued that some of their versions display traces of medieval dualist editorial interventions and interpolations ${ }^{43}$. Some of the Paradise material in these apocryphal works possesses interesting cosmographic features but since it does not show manifest dualist elements or tendencies, it would be premature and risky to integrate this material into a discussion of the Paradise tradition in medieval Christian dualism ${ }^{44}$. Again, the future study of the intertextual patterns between these texts and Bogomil adoptions of the shared pseudepigraphic heritage in medieval Byzantine and Orthodox Slavonic environments could yield interesting results in the sphere of the development of ideas about the cosmogra-

${ }^{41}$ Texts respectively in А. МилтеновА, op. cit., p. 51; Й. ИвАнов, op. cit., p. 260-261. On the place of this particular passage on Satanael and the Tree in Paradise in the manuscript tradition of Razumnik, seе А. Милтенова, Erotapokriseis. Сәчинения от кратки въпроси и отговори в старобългарската литература, София 2004, p. 251-253.

${ }^{42}$ On the Beginning of the World, ed. Й. Иванов, ор. cit., p. 323; on these parallels between the Paradise material in Interrogatio Iohannis and On the Beginning of the World, cf. Й. ИвАнов, op. cit., p. 70.

${ }^{43}$ For a critical survey of the evidence for and state of debate of such dualist editorial interventions in these apocryphal works, see Y. STOYAnov, Apocryphal Themes and Apocalyptic Traditions..., p. 114191; in the case of the Battle between Archangel Michael and Satanael, the issue of dualist involvement in the text has been revisited by Г. Минчев, Един богомилски текст? Слово на св. Йоан Златоуст как Михаил победи Сатанаил, Pbg 34.4, 2010, p. 17-46; G. Minczew, John Chrysostom's Tale on How Michael Vanquished Satanael - a Bogomil text?, SCer 1, 2011, p. 23-55.

${ }^{44}$ Significantly, although Battle between Archangel Michael and Satanael recounts God's creation of Paradise and attributes actual demiurgic acts to Satanael (he creates his own heavens, dark sun, moon and stars - a parallel satanic universe), these acts do not include the creation of an alternative paradise. On the dualist tendencies and type of cosmic dualism advanced in the apocryphon, see Y. Stoyanov, op. cit., p. 120-122. 
phy of Paradise in normative, heterodox and heretical medieval Eastern Orthodox milieus.

Significantly, recent studies of the paradise narrative in 3 Baruch 4 (especially the theme of the angelic planting of the Garden of Eden and its destruction by the waters of the Flood) have shed a new light on its dualist tendencies and potential which conditioned the interest of medieval dualist scribes in appropriating and reworking some of its elements. These recent trends of research have shown, for example, that whereas the number and list of planting angels and the type of planted trees in the Slavonic version of 3 Baruch 4 displays respectively continuity with rabbinic traditions and Philo ${ }^{45}$, the very notion of the five trees in Paradise finds parallels not only in Philo but also in Gnostic and Manichaean traditions ${ }^{46}$. The chronology and the above two main elements of the Paradise narrative in 3 Baruch 4 is also shared in the Qumran and Manichaean fragments of the Book of Giants $^{47}$ and the later related Midrash of Shemhazai and Azael ${ }^{48}$. Another crucial element which, as persuasively argued by Orlov, is also shared by these two related streams of paradise material is the involvement of a fallen angelic being (or beings) in the planting of the Garden of Eden - respectively Samael (Satanael) in 3 Baruch and the fallen angels of the Enochic tradition, the Watchers in the Book of Giants ${ }^{49}$. Paradise assumes thus a central locus in cosmic history and topography by becoming the primordial place where a superhuman being (or beings) raised the paradigmatic rebellion against the original heavenly order and divine authority.

The extant evidence (internal and external) of Eastern Christian medieval dualism is very scanty, focused principally on its theological, diabological and docetic tenets and does not allow a proper reconstruction of its adoption and development of the Paradise tradition vis-à-vis the better attested moderate dualist Paradise narrative. The corresponding records of Western Christian (Cathar) radical dualism are more detailed and offer some indications that its appropriation and revisions of the Paradise tradition may have followed their distinct exegetical dynamics, which also had implications for the sphere of cosmography. The various Cathar versions of the radical dualist formula of two primordial

45 D.C. Harlow, op. cit., p. 125-126, 198-208 passim; A. Kulik, 3 Baruch..., p. 198-208 passim; A. KULIK, Veritas Slavica: On the Value of Slavonic Evidence for the Early Apocalyptic Tradition, ПК 38, 2010, p. $1-65(40-41$.

46 A. Kulıк, 3 Baruch..., p. 204-206; A. Kulik, Veritas Slavica..., p. 40-41.

47 Cf. the texts in: W.B. Henning, The Book of the Giants, BSOAS 11, 1943, p. 52-74; J. Milik, M. BLACK, The Books of Enoch. Aramaic Fragments of Qumrân Cave 4, Oxford 1976, p. 317; L. STUCKeNBRUCK, The Book of Giants from Qumran: Texts, Translation, and Commentary, Tübingen 1997.

${ }^{48}$ Hebrew text and translation in: J. MiLik, M Black, op. cit., p. 321-328; on the shared paradise material in 3 Baruch 4, the Qumran and Manichaean fragments of the Book of Giants and Midrash of Shemhazai and Azael, cf. A. OrLov, The Flooded Arboretums: The Garden Traditions in the Slavonic Version of 3 Baruch and in the Book of Giants, CBQ 65, 2003, p. 184-201.

49 A. Orlov, op. cit.; cf. J.C. Reeves, Jewish Lore in Manichaean Cosmogony, Cincinnati 1992, p. 95-96; L. STUCKENBRUCK, op. cit., 114. 
fundamental principles that were opposed from the very beginning naturally developed cosmogonies in which the God of Darkness was regarded as the creator of the four elements, the visible heaven, the moon, the stars and everything on earth, while the God of Light was the creator of everlasting, eternal things, four alternative elements of his own and another heaven, moon and stars ${ }^{50}$. Such a cosmogony in which the two realms of light and darkness are coeval and totally separate could lead to a greater focus on the transcosmic nature of any Paradise envisaged in the kingdom of Light and its "heavenly" connotations. This is indeed the case in the heavenly cosmography of Paradise advanced in the radical dualist anonymous "Manichaean" Treatise, portions of which are reproduced in Durand of Huesca's early thirteenth-century Liber contra manicheos ${ }^{51}$. In the sixth excerpt from the treatise the "new heaven and the new earth" of Isaiah 66, 22, 2 Peter 3, 13 and Revelation 21, 1 are recognized as the Paradise of the celestial kingdom in which are located the holy Jerusalem, the tree of life, river of life and the angelic court of the Father. Against the background of this heavenly cosmography of the Paradise in the kingdom of Light in this version of Cathar radical dualism, it would be worthwhile to recollect that generally in such Cathar radical dualist teachings Satan-Lucifer (seen on occasions as the son of an eternal evil god) initiates an attack on the heaven of the good God, causing the fall of the angels and the imprisonment of angelic souls in human bodies; in the teachings of the Albanenses of North Italy he can also be envisaged as sexually assaulting the celestial wife of the good God ${ }^{52}$ which could reflect Eve's seduction by Samael/ Satan in the Paradise narratives of medieval moderate Christian dualism ${ }^{53}$.

Further study of the cosmography of the celestial Paradise and the sexual dimension of the evil principle's onslaught on the "Good Creation" in medieval radical dualist teachings could establish whether such correlation between the Paradise narratives of the two principal currents of medieval dualism actually existed. Trends in medieval Christian dualism could also develop an interest in the cosmography and soteriological role of terrestrial paradise, as evinced by teachings of the second person in the hierarchy of the moderate dualist Cathar Church of Concorezzo in North Italy, Desiderius ${ }^{54}$. Desiderius, whose doctri-

\footnotetext{
${ }^{50}$ Cf. for example, the system of Cathar absolute dualism recorded in: Moneta of Cremona, op. cit., Book 1, Preface, p. 2-4.

${ }^{51}$ Published by C. Thouzellier, Un traité cathare inédit du début du XIII siècle d'après le Liber contra manicheos de Durand de Huesca, Louvain 1961, p. 87-113.

52 The radical dualist teachings of the Albanenses are recorded in the treatise Brevis summula contra herrores notatos hereticorum, [in:] La somme des autorités à l'usage des prédicateurs méridionaux au XIII siècle, ed. C. DouaIs, Paris 1896, p. 114-143.

${ }^{53}$ For a brief discussion of such a possible interrelation between the Albanenses' and moderate dualist Paradise narratives, cf. Y. SToYAnov, The Other God..., p. 276-277.

${ }^{54}$ Desiderius' teachings are recorded in: Anselm of Alessandria, Tractatus de hereticis, [in:] La Hiérarchie cathare en Italie, II: Le "Tractatus de hereticis d'Anselme d'Alexandrie", ed. A. DondaINE, AFP 19,1949 , p. 280-312 (311).
} 
nal innovations eventually created a split in this Cathar church, attempted to formulate a more somatic version of Bogomil-Cathar Christology by asserting that Jesus assumed a body of 'the stuff of Adam ${ }^{55}$, a teaching which parted with traditional Bogomil-Cathar docetic doctrine that Christ never took an actual physical body, but did so only in appearance. Desiderius, moreover, manifested a very non-docetic concern with the whereabouts of the physical body of Jesus Christ, which, he claimed, was put in a terrestrial Paradise, where also resided Virgin Mary and John the Evangelist along with the souls of the righteous dead. According to Desiderius this righteous company will stay in the terrestrial Paradise until the Day of Judgement when Christ will put it again to rise and judge all good and evil ${ }^{56}$.

It is obvious that Desiderius' teachings on terrestrial Paradise are in disagreement with the other extant medieval dualist renditions of the Paradise tradition but may reflect contemporaneous debates and opinions on the existence, nature and cosmography of Paradise in medieval Christendom. Medieval dualism did not develop in isolation from contemporaneous medieval intellectual currents and changing cultural trends, but interacted with them at varying degrees of intensity during its existence. Indeed recent studies have demonstrated the importance of high learning in Northern French ${ }^{57}$ Italian $^{58}$ and Languedoc Catharism ${ }^{59}$, demonstrating that the Cathars variously participated in the wider theological and educational trends of the late twelfth and early thirteenth centuries ${ }^{60}$. Exploring to what extent speculations on Paradise (heavenly and terrestrial) may have played a role in these patterns of interaction between dualist heresy, literacy and contemporaneous intellectual pursuits of this period may prove another fruitful area for future exploration of medieval perspectives on Paradise.

The extant Paradise narratives in medieval moderate and radical Christian dualism and their cosmographic relevance certainly lack the complexities of earlier Gnostic representations and conceptualizations of the Paradise theme, with their cosmological, soteriological and eschatological dimensions and repercussions. But this may reflect the insufficiently explored evidence (internal and external) of the development of the Paradise narrative in medieval Christian

\footnotetext{
${ }^{55}$ Ibidem, p. 311.

56 Ibidem, p. 311-312.

${ }^{57}$ Cf. for example, P. Biller, Northern Cathars and Higher Learning, [in:] The Medieval Church: Universities, Heresy, and the Religious Life, Essays in Honour of G. Leff, ed. P. Biller, B. Dobson, Woodbridge 1999, p. 25-52.

${ }^{58}$ L. Paolini, Italian Catharism and Written Culture, [in:] Heresy and Literacy 1000-1530, ed. P. BiLler, A. Hudson, Cambridge 1994, p. 83-103.

59 P. BiLler, The Cathars of Languedoc and Written Materials, [in:] Heresy and Literacy..., p. 61-82, esp. p. $80-82$.

${ }^{60}$ See the summary of the evidence of and approaches to this phenomenon in: Y. STOYANOv, The Other God..., p. 261.
} 
dualism. With the current level of research on the relevant primary sources on Eastern Christian dualism, it is difficult to establish as yet whether more material pertaining to Paradise in works which served as sources for a number of its teachings like 2 Enoch and 3 Baruch was adopted and re-interpreted in their narratives and theological and cosmological schemas. This may prove a useful area for a more systematic study, given the role of 2 Enoch in medieval Byzantine and Orthodox Slavonic speculations on Paradise, as evidenced by the textual interrelations between its long version and the Greek and Slavonic manuscripts of the anti-Catholic satirical tract The Disputation of Panagiot and Azimit ${ }^{61}$. Significantly, even before its medieval circulation in Byzantine and Orthodox Slavonic milieus the Paradise material in the original version of 2 Enoch had already served as a source for Manichaean dualist teachings concerning the heavenly paradise and the heavenly Tree of Life, as convincingly argued by J.C. Reeves ${ }^{62}$. Another area that would require future exploration in this context is whether the adoption of heavenly ascent notions from earlier pseudepigrapha into new dualist versions of visionary mysticism, as attested among some Bogomil and Cathar circles ${ }^{63}$, included also re-interpretations of Paul's account of ascent to the third heaven and Paradise (2 Corinthians 12, 1-4) ${ }^{64}$.

Further and more systematic investigation of the Paradise problematic in the sources for Eastern and Western Christian medieval dualism may thus prove fruitful in all these areas of study. It is hoped that this preliminary survey of medieval dualist conceptions of biblical Paradise shows also once more that, among other things, the doctrinal evidence for Bogomilism and Catharism is too complex and polyvalent to be defined or ignored apriori as representing medieval heresiological constructs drawing on earlier heresiological texts and stereotypes. Thus any future study aiming to argue, for example, that the various reported accounts of Cathar cosmogony, cosmology, satanology, Christology, soteriology,

${ }^{61}$ For the Slavonic texts of The Disputation of Panagiot and Azimit, cf.: А.Н. Попов, Историко-литературный обзор древнерусских полемических сочинений против татиниан, Москва 1875, p. 211-283; on the textual interrelations between the cosmographic Paradise material in the long version of 2 Enoch and The Disputation of Panagiot and Azimit, cf. M. Соколов, op. cit., vol. II, p. 136-144; A. VAILLANT, Le Livre des secrets d'Hènoch: Texte slave et traduction français, Paris 1952, p. XVI-XVII; F. ANDersen, The Sun in 2 Enoch, [in:] L'église des deux Alliances: Mémorial Annie Jaubert (1912-1980), ed. B. Lourié, A. Orlov, M. Petit, Piscataway 2008, p. 1-38 passim.

${ }^{62}$ J.C. Reeves, Jewish Pseudepigrapha in Manichaean Literature: The Influence of the Enochic Library, [in:] Tracing the Threads: Studies in the Vitality of Jewish Pseudepigrapha, ed. J.C. Reeves, Atlanta 1994, p. 184-191.

${ }_{63}$ Y. Stoyanov, The Other God..., p. 261-262; Y. Stoyanov, Apocryphal Themes and Apocalyptic Traditions..., p. 235.

${ }^{64}$ For a recent treatment of the Paradise theme in 2 Corinthians 12, 1-4 wider New Testament, pseudepigraphic and rabbinic frameworks, cf. G. Macaskill, Paradise in the New Testament, [in:] Paradise in Antiquity: Jewish and Christian Views, ed. M. Воскмuenl, G.A.G. Stroumsa, Cambridge 2010, p. 67-71. 
biblical history and eschatology are the end result of sets of discourses forged by their clerical adversaries and attributed to communities and individuals they intended to repress, need to base such arguments on solid and cautious text-critical analysis of the extant doctrinal evidence in toto. Without such analysis it would be impossible to establish a plausible textual chain of transmission for the respective narratives, imagery, symbolism, etc., in the sources for Bogomilism and Catharism and distinguish a textual layer that could represent a genuine "heretical" belief from one that reiterates inherited heresiological stereotypes. In the opinion of the present author such text-critical treatment of the primary sources to first establish the most plausible literary and theological provenance of the respective teachings attributed to medieval Christian dualist groups or individuals still remains indispensable to the study of medieval heresy and needs to precede the application of models and approaches drawn from contemporary anthropological and sociological theory to the source material.

In the case of the notions of Paradise in medieval Christian dualism such analysis could show that along with allegorical and inverted readings of the Genesis Eden narrative, other doctrinal concerns also may have played a role in medieval Christian dualist approaches to and revisions of the Paradise tradition.

\begin{abstract}
The article intends to draw attention to some of the most significant and telling appropriations of traditional themes of Biblical paradise in medieval Christian dualism (namely, Paulicianism, Bogomilism and related groups in Eastern Christendom and Catharism in Western Christendom) and initiate discussion on the important but presently not always explicable problem of their theological and literary provenance. The significance of this problematic is highlighted by the increasing amount of direct and indirect evidence of the role played by a number of early Jewish and Christian pseudepigraphic works in the formation of medieval Christian dualist cosmogonic, cosmological, satanological, Christological and biblical history traditions. The preliminary survey of medieval dualist conceptions of biblical Paradise shows also once more that the doctrinal evidence for Bogomilism and Catharism is too complex and polyvalent to be defined or ignored apriori as representing medieval heresiological constructs drawing on earlier heresiological texts and stereotypes. The material examined in the article shows that the text-critical treatment of the primary sources to first establish the most plausible literary and theological provenance of the respective teachings attributed to medieval Christian dualist groups or individuals still remains indispensable to the study of medieval heresy and needs to precede the application of models and approaches drawn from contemporary anthropological and sociological theory to the source material.
\end{abstract}

Yuri Stoyanov

Department of the Near and Middle East Faculty of Languages and Cultures School of Oriental and African Studies

University of London

Thornhaugh Street, Russell Square London WC1H 0XG, United Kingdom ys3@soas.sc.uk 